\title{
DPF3 wt Allele
}

National Cancer Institute

\section{Source}

National Cancer Institute. DPF3 wt Allele. NCI Thesaurus. Code C157311.

Human DPF3 wild-type allele is located in the vicinity of $14 \mathrm{q} 24.2$ and is approximately 285 $\mathrm{kb}$ in length. This allele, which encodes zinc finger protein DPF3, plays a role in chromatin remodeling in differentiated neurons. 